\title{
FLEXIBILITY OF ADJUSTMENT TO SHOCKS: ECONOMIC GROWTH AND VOLATILITY OF MIDDLE-INCOME COUNTRIES BEFORE AND AFTER THE GLOBAL FINANCIAL CRISIS OF 2008
}

\author{
Joshua Aizenman \\ Yothin Jinjarak \\ Gemma Estrada \\ Shu Tian \\ Working Paper 23467 \\ http://www.nber.org/papers/w23467 \\ NATIONAL BUREAU OF ECONOMIC RESEARCH \\ 1050 Massachusetts Avenue \\ Cambridge, MA 02138 \\ June 2017
}

Donghyun Park provided overall guidance for the paper. Ilkin Huseynov provided able assistance with the data. Akiko Terada-Hagiwara and participants at the ADB workshop on "Transcending the Middle-Income Challenge" provided useful comments and suggestions. Financial support from the ADB is gratefully acknowledged. Any errors are ours. The views expressed herein are those of the authors and do not necessarily reflect the views of the Asian Development Bank (ADB) and the National Bureau of Economic Research. Financial support from the ADB is gratefully acknowledged.

NBER working papers are circulated for discussion and comment purposes. They have not been peer-reviewed or been subject to the review by the NBER Board of Directors that accompanies official NBER publications.

(C) 2017 by Joshua Aizenman, Yothin Jinjarak, Gemma Estrada, and Shu Tian. All rights reserved. Short sections of text, not to exceed two paragraphs, may be quoted without explicit permission provided that full credit, including $\odot$ notice, is given to the source. 
Flexibility of Adjustment to Shocks: Economic Growth and Volatility of Middle-Income Countries Before and After the Global Financial Crisis of 2008

Joshua Aizenman, Yothin Jinjarak, Gemma Estrada, and Shu Tian

NBER Working Paper No. 23467

June 2017

JEL No. E02,F43

\begin{abstract}
The pronounced and persistent impact of the global financial crisis of 2008 motivates our empirical analysis of the role of institutions and macroeconomic fundamentals on countries' adjustment to shocks. Our empirical analysis shows that the associations of growth level, growth volatility, shocks, institutions, and macroeconomic fundamentals have changed in important ways after the crisis. GDP growth across countries has become more dependent on external factors, including global growth, global oil prices, and global financial volatility. After accounting for the effects global shocks, we find that several factors facilitate adjustment to shocks in middle income countries. Education attainment, share of manufacturing output in GDP, and exchange rate stability increase the level of economic growth, while exchange rate flexibility, education attainment, and lack of political polarization reduce the volatility of economic growth. Countries cope with shocks better in the short to medium term by using appropriate policy tools and having good long-term fundamentals.

Joshua Aizenman

Economics and SIR

USC

University Park

Los Angeles, CA 90089-0043

and NBER

aizenman@usc.edu

Yothin Jinjarak

School of Economics and Finance

Victoria University of Wellington

PO Box 600

23 Lambton Quay, Wellington

New Zealand 6140

yothin.jinjarak@vuw.ac.nz

Gemma Estrada

Asian Development Bank

6 ADB Ave, Ortigas Center, Mandaluyong

Philippines

gestrada@adb.org

Shu Tian

Asian Development Bank

6 ADB Ave, Ortigas Center, Mandaluyong

Manila, Philippines

stian@adb.org
\end{abstract}




\section{Introduction}

The global financial crisis of 2007-2009 marked a watershed moment in postwar economic history of the world. Prior to the global crisis, most financial and economic crises occurred in emerging markets in Asia, Latin America and elsewhere. While those crises inflicted a great deal of economic and social hardship on the affected economies, the spillover effects of those crises on other economies was by and large limited. For example, the Asian financial crisis of 1997-1998 sharply curtailed growth and caused high unemployment and other humanitarian suffering in four high-flying East and Southeast Asian economies, namely Indonesia, Korea, Malaysia and Thailand, but those effects did not spill over to the rest of the world. Similarly, the adverse effects of crises that Argentina, Mexico, and other Latin American countries suffered prior to the global crisis were mostly confined to the crisis-hit economies themselves.

What is qualitatively different about the global financial crisis was that it broke out in the U.S., the world's largest economy and home to world's biggest, deepest and most liquid and sophisticated financial markets. As such, it was bound to have incomparably larger effects on the rest of the world and so it proved. The crisis was rooted in the U.S. subprime mortgage crisis which, in turn, was rooted in colossal market failures in the U.S. housing and financial markets. Simply put, in their quest for yield, U.S. banks lent far too much mortgage to borrowers with poor credit ratings, fuelling a housing bubble that burst when Lehman Brothers went under. The crisis paralyzed credit flows in the U.S. and spread like wildfire across the Atlantic to Europe, due to the heavy exposure of many European banks to U.S. subprime mortgage assets. The primary channel of crisis transmission to emerging markets was via reduction of trade and disruption of capital flows. 
As credit flows seized up, business and consumer confidence took a major hit, and investment and consumption plummeted, crimping growth. The global crisis thus spread quickly from the financial markets to the real economy. The U.S. and other advanced economies went into recession and in 2009 suffered a contraction of output. Although emerging markets as a whole grew in 2009, emerging-market growth was not enough to offset advanced-economy contraction, and global GDP fell marginally for the first and only time in the postwar period (Figure 1). While the decline in global GDP was marginal, the decline in global trade was more substantial (Figure 2). When the global crisis broke out, there were genuine, widespread fears of another Great Depression, the interwar catastrophe that devastated the world economy. In fact, only concerted, forceful fiscal and monetary policy interventions by governments and central banks around the world averted another Great Depression. 
Figure 1

GDP growth of advanced economies, emerging market and developing economies, and the world, 2000-2015

$\%$

12

8

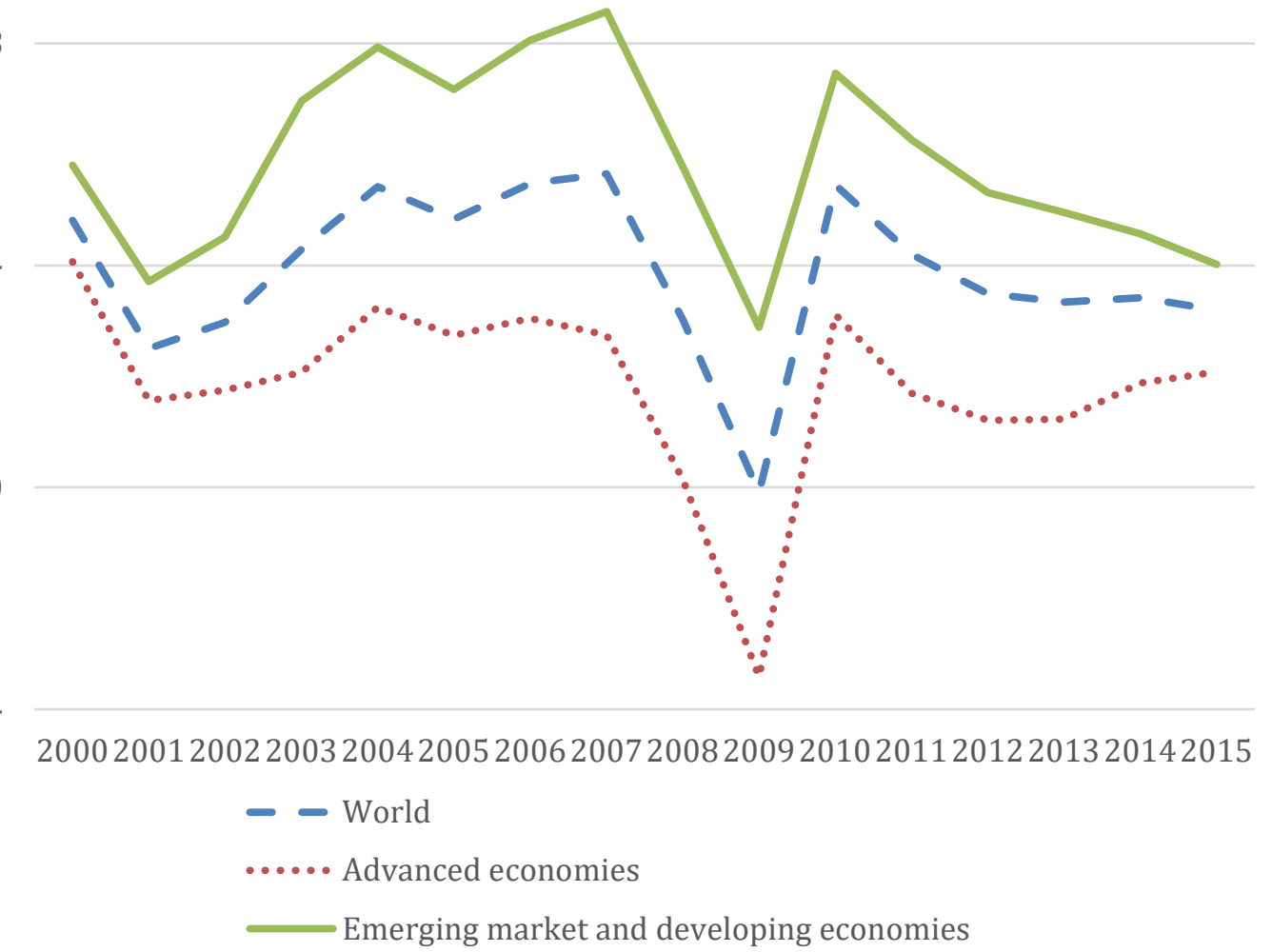

Source: International Monetary Fund, World Economic Outlook database October 2016. 
Figure 2

Global Trade Growth

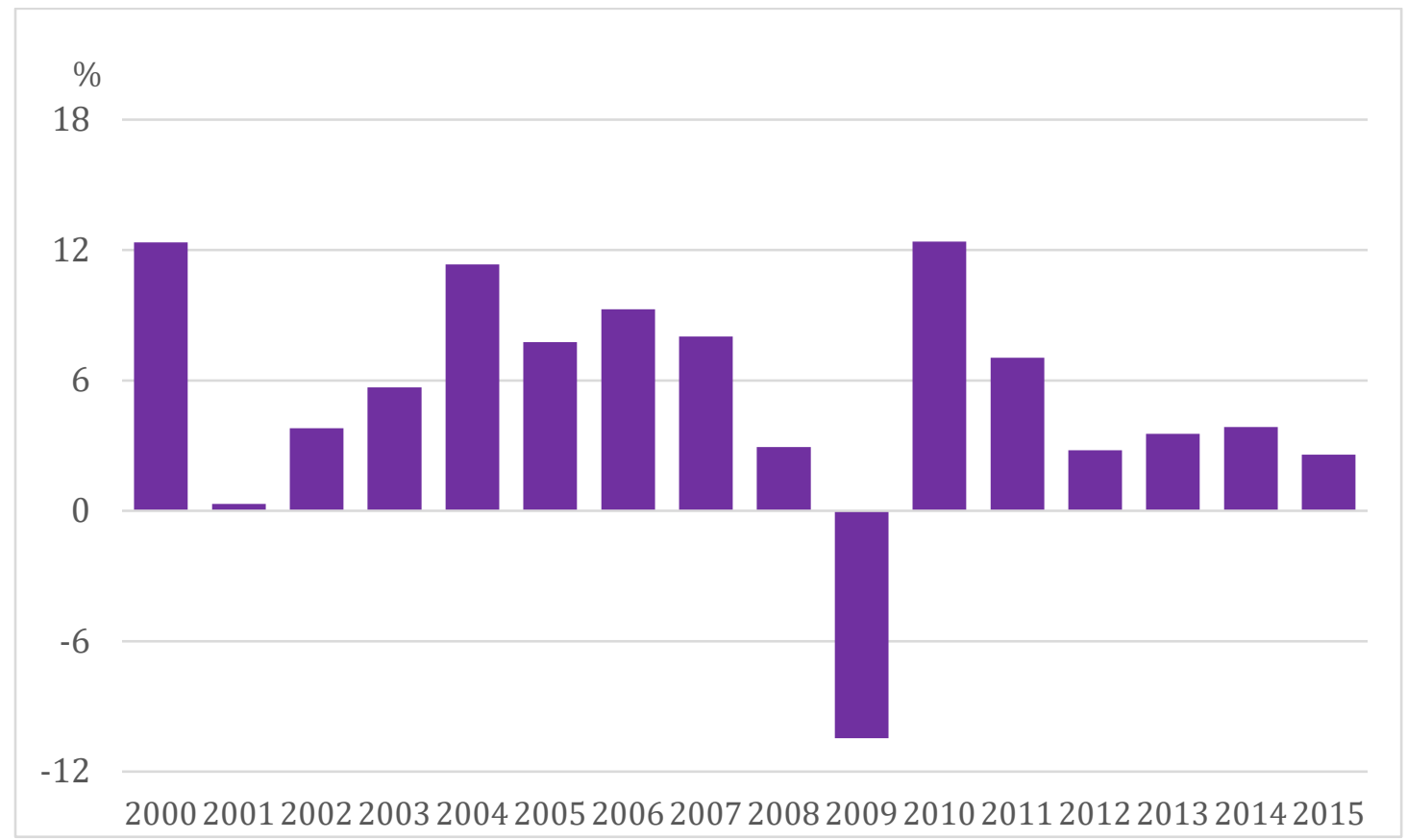

Source: International Monetary Fund, World Economic Outlook database October 2016.

There is a visible slowdown of global growth momentum since the global financial crisis. In other words, the effects of the crisis continue to reverberate. Initially, the slowdown was more evident in the advanced economies, giving rise to the notion of a two-speed economy of fast-growing emerging markets and slow-growing advanced economies. However, in more recent years, the growth deceleration has spread to emerging markets, causing the world economy as a whole to slow down. The effect of the global financial crisis on global growth is thus significant and persistent. In addition, a number of structural factors also contributed to the weakening of the world economy since 2008. For example, China's growth has moderated in recent years, largely due to structural factors such as population aging, convergence toward high income, and rebalancing toward domestic demand. Above all, population aging is not confined to China but poses an increasingly global headwind against growth. Whereas the demographic transition toward older population structures was almost exclusively a 
rich-country trend, in recent decades it has spread to developing countries, including much of Asia (Figure 3).

\section{Figure 3}

Share of Population, Aged 65 and Above, Selected Asian Countries

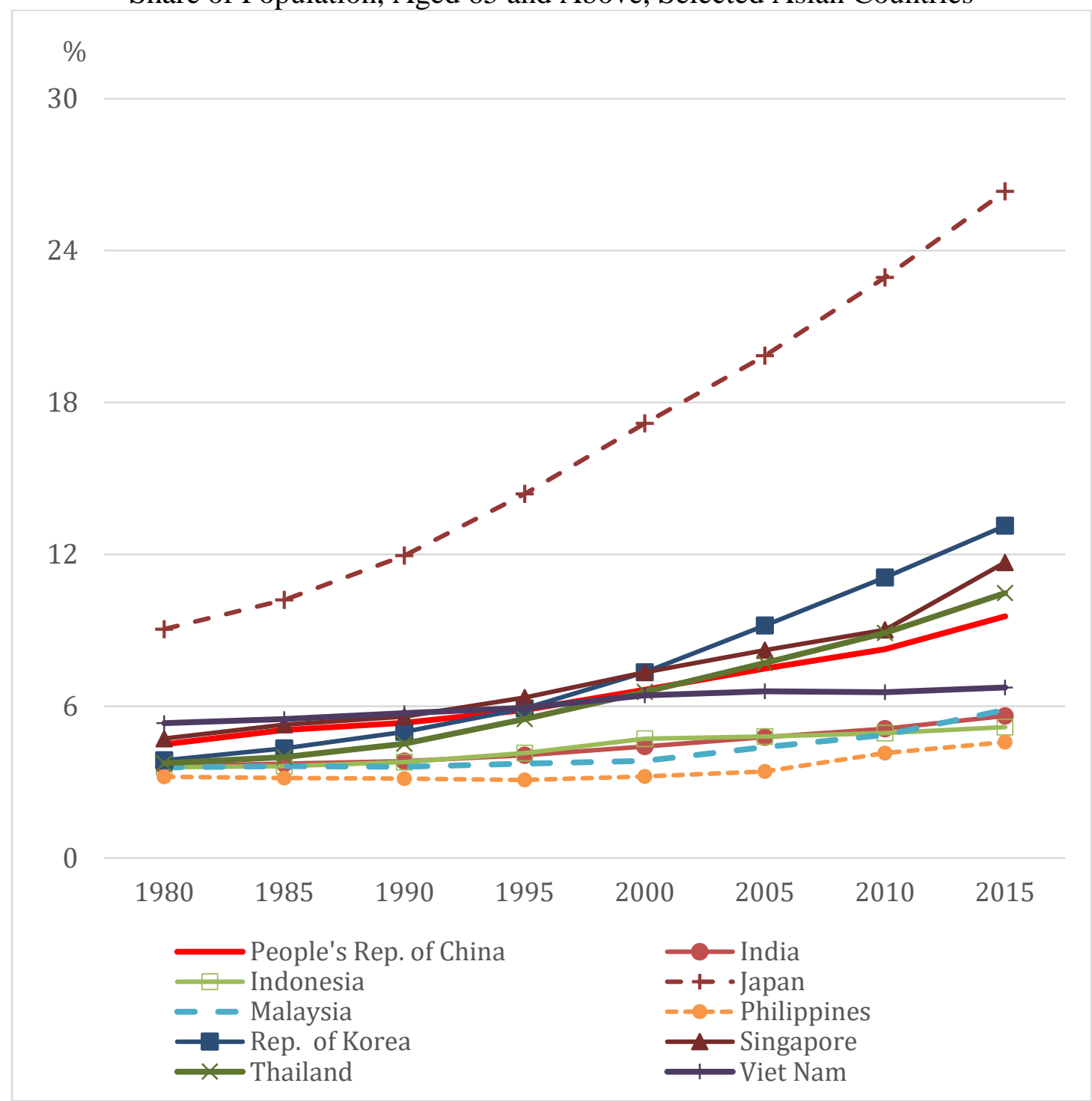

Source: United Nations, Department of Economic and Social Affairs, Population Division (2015). World Population Prospects: The 2015 Revision, DVD Edition.

While structural factors such as population aging are also at play, the size and persistence of the slowdown of global growth momentum since the global financial crisis suggests that it is worthwhile to examine and compare vulnerability to economic shocks before and after that crisis. While it is admittedly too early to tell whether the global crisis will permanently lower the global growth trajectory, nevertheless it has so far been a game changer that has had profound effect on the global economic and 
financial landscape. One natural question that arises is whether vulnerability and adjustment to shocks has changed in fundamental ways since the crisis. While this question is relevant for all countries, it is perhaps especially relevant for middle income countries in light of their growing integration into the world economy. For example, whereas much of foreign capital which flows into low income countries are foreign aid and foreign direct investment (FDI) in natural resource industries, middle income countries receive greater amounts of potentially volatile short-term capital inflows, rendering them more vulnerable to shocks. Furthermore, the policy tools and institutions for coping with shocks tend to be less developed in middle income countries than in high income countries. Of particular interest is the volatility and level of growth.

The rest of this paper is organized as follows. Section 2 briefly reviews the literature of studies that examine the factors which hinder or facilitate smooth growth adjustment to macro shocks. Section 3 describes the data and empirical framework. Section 4 reports and discusses the main empirical findings. Section 5 concludes the paper. 


\section{Selective Literature Review}

A key feature of developing countries is their greater exposure to domestic and external macroeconomics shocks than the industrial countries (Hausmann and Gavin (1996)). Understanding the root causes of this exposure, and ways to mitigate it remains a vibrant research agenda. This section provides a selective review of the recent literature on this important issue. The higher volatility of developing countries reflects the larger size and greater volatility of exogenous external shocks, such as terms of trade volatility, greater vulnerability of developing countries to such shocks, sometimes exacerbated by volatile domestic policy, along with limited absorption and adjustment capacities.

While the association between shocks, investment, and economic growth is generally ambiguous (Caballero (1991) and the references therein), the empirical research during recent decades convincingly showed a negative association between macroeconomic volatility and growth. Pindyck and Solimano (1993) showed that decade-to-decade changes in volatility have a moderate effect on investment, and the effect is greater for developing countries than for industrialized countries. Aizenman and Marion (1993) showed that policy uncertainty is negatively associated with private investment and growth in developing countries. Ramey and Ramey (1995) found a negative association between growth and volatility in a comprehensive study that included the OECD and the developing countries. ${ }^{2}$ The study linked volatility to the debate about the cost of the business cycle. ${ }^{3}$

\footnotetext{
${ }^{2}$ Ramey and Ramey (1995) failed to detect a negative association of macro volatility to investment. Aizenman and Marion (1999) noted that the Ramey and Ramey (1995) reflects their focus on aggregate investment, but there is a robust negative association of macro volatility and private investment.

${ }^{3}$ These results are in sharp contrast to Lucas (1987), who showed in a calibrated model that the cost of business cycle volatility is of second order magnitude. Lucas' results reflected his presumption that the
} 
A seminal paper by Rodrik (1999) identified weak institutions and latent social conflict as the main reason for the negative impact of volatility on growth. He emphasized the manner in which social conflicts interact with external shock on the one hand, and the domestic institutions of conflict-management on the other. Countries that experienced the sharpest drops in growth after 1975 were those with divided societies, as measured by indicators of inequality, ethnic fragmentation, and the like, and with weak institutions of conflict management, proxied by indicators of the quality of governmental institutions, rule of law, democratic rights, and social safety nets. The implication is that strong institutions dampen volatility, while weak institutions magnify the negative consequences of volatility.

Easterly, Islam, and Stiglitz (2000) honed in on the financial system as the primary factor in growth volatility. They found that up to a point, greater financial depth is associated with lower growth volatility; but as financial depth and leverage grow, the financial sector could become a source of macroeconomic vulnerability. Aghion et al. (2009) offered empirical evidence that real exchange rate volatility can have a significant impact on long-term rate of productivity growth, but the effect depends critically on a country's level of financial development.

Acemoglu, Johnson, Robinson, and Thaichoren (2003) took the primacy of institutions a step further, arguing that crises are caused by bad macroeconomic policies, which increase volatility and lower growth. But more fundamentally, bad macro policies are the product of weak institutions. In order to avoid problems with endogeneity and omitted variables, they develop a technique to isolate the historically determined component of institutions, based on the colonization strategy pursed by

economic growth is independent from business cycle volatility, a presumption that is not supported by the data. 
European settlers, and show that this is the critical factor in explaining volatility, crises, and growth.

Macroeconomic volatility depends on economic structure - e.g. sectoral composition of output, trade openness, and financial openness - as well on the economy's institutional structure and economic policy regimes. While the openness of the economy may be given in the short run, in the long run it is the endogenous outcome of geography, history, demographics, policies, institutions, and other factors. We review below several of these channels

IDB (1995) and Hausmann and Gavin (1996) found that higher volatility was associated with both lower growth and higher inequality, with the latter tending to be highly persistent. The impact of volatility on inequality was transmitted mainly through educational attainment. Furthermore, institutional shock absorbers are important determinants of macroeconomic volatility. Specifically, deep financial markets act as a shock absorber. Furthermore, the exchange-rate regime has a significant impact on volatility. In particular, pegged exchange rate regimes appear to stabilize the real exchange rate, at the cost of destabilizing real output. Switches between exchange rate regimes are highly destabilizing, suggesting that unsustainable regimes are destabilizing.

The follow up literature provided ample evidence that, for developing and emerging market countries, less flexible exchange rate regimes are associated with slower growth, as well as with greater output volatility [Broda (2004), Edwards \& Levy-Yeyati (2005), and Céspedes \& Velasco (2012)]. In a related research by the IDB, Gavin at al. (1996) identified the procyclicality of fiscal policy as a major amplifier of developing countries' vulnerability to shocks. Remarkably, over the last two decades the fiscal policies of about a third of developing countries have become 
counter-cyclical. Chile is a case in point, with institutional design facilitating smoother counter-cyclical adjustment of fiscal and other macroeconomic policies [see Frankel (2011) and Frankel, Vegh, and Vuletin (2013)].

This discussion can be framed in the broader context of influential changes in the configuration of Mundell's Trilemma following the collapse of the Bretton-Woods system. Remarkably, emerging markets (EMs) increased their financial integration in the 1990s, a process that heightened their vulnerability to shocks. In some vulnerable countries, capital flight induced banking and balance of payment crises, crises that were dubbed as ‘sudden stop crises’ by Calvo (1998) and Calvo and Reinhart (2000), and studied by Eichengreen et al. (2008). The position of developing countries was further compromised by their inability to borrow in their own currency - the original sin articulated by Eichengreen, Hausmann and Panizza (2002) - and by their limited and uncertain access to capital markets due to high sovereign risk.

In line with the Trilemma's prediction, over time the growing financial integration of emerging markets came at a cost of lower exchange rate stability - i.e. greater managed flexibility of the exchange rate. Through a trial and error learning process, emerging markets gradually found the trilemma middle ground-greater exchange rate flexibility, limited financial integration, and controlled monetary independence, buffered by macroeconomic prudence. This approach is evident in precautionary hoarding of international reserves, aimed at reducing the frequency and the costs of capital flight crises.

Relevant studies include Aizenman and Lee (2007) and by Aizenman, Chinn and Ito (2011, 2013) and other papers listed in Aizenman, Chinn and Ito’s Trilemma Indexes webpage (http://web.pdx.edu/ ito/trilemma_indexes.htm). They found that greater monetary independence is associated with lower output volatility while greater 
exchange rate stability is associated with greater output volatility, which can be mitigated if a country has sizable international reserves. Prudent management of buffers like international reserves and sovereign wealth funds can substantially reduce the real exchange rate volatility associated with terms of trade shocks that affect commodity countries (Aizenman, Edwards and Riera-Crichton 2012, Aizenman and Riera-Crichton 2014).

\section{Empirical Framework}

In this section, we describe the data and empirical framework used for our analysis. We put together data on real GDP growth, country-specific and external shocks, institutions and fundamentals for a set of high-income, middle-income, and low-income countries spanning 1990-2015. Our final sample period is 2004-2014. Most series are from the Economist Intelligence Unit, Federal Reserve Economic Data, World Economic Outlook database, World Development Indicators, and World Trade Flow database, supplemented with series from several sources. Data sources, definitions, and year coverage are provided in the Appendix.

\subsection{GDP Growth and Volatility: A First Look}

For our main variables of interests - GDP growth and GDP volatility - we follow the country-income classification in Han and Wei (2015) to classify country observations into income groups, as follows:

Extremely low-income economies: GDP per capita (2011 PPP) < \$1,096;

Low-income economies: \$1,096 < GDP per capita < \$2,527;

Lower-middle-income economies: \$2,527 < GDP per capita $<\$ 5,223$

Upper-middle-income economies: \$5,223 < GDP per capita $<\$ 17,600$ 
High-income economies are countries with GDP per capita $>\$ 17,600$

Of course, the adjustment of GDP growth and volatility does not necessarily follow the same pattern all across countries in an income group. In any case, we will also examine the patterns of data in the whole sample regardless of the income classification.

Figure 4 plots for each income group the GDP growth and GDP volatility, respectively. Comparing across income groups, GDP growth of the upper-middle income and high-income countries have shown no tendency to fully recover from the crisis after almost ten years. These simple plots also suggest that GDP volatility declined in middle-income countries and high-income countries after peaking in 20092011, but remains above the level before the crisis.

\subsection{Empirical Approach}

The study aims to uncover how countries cope with crises and shocks. We approach the subject by looking at whether better coping mechanisms are associated, on average, with lower volatility of GDP growth, and higher average growth rates. More concretely, the research questions for our empirical analysis are the following:

(i) What are the conditions enhancing faster and smoother adjustment of growth to shocks, especially for middle-income countries, before and after a crisis?

(ii) Is faster and smoother adjustment to shocks associated with higher average growth rate and/or lower output volatility, before and after a crisis? 
Figure 4. GDP Growth and Volatility across Income Groups.

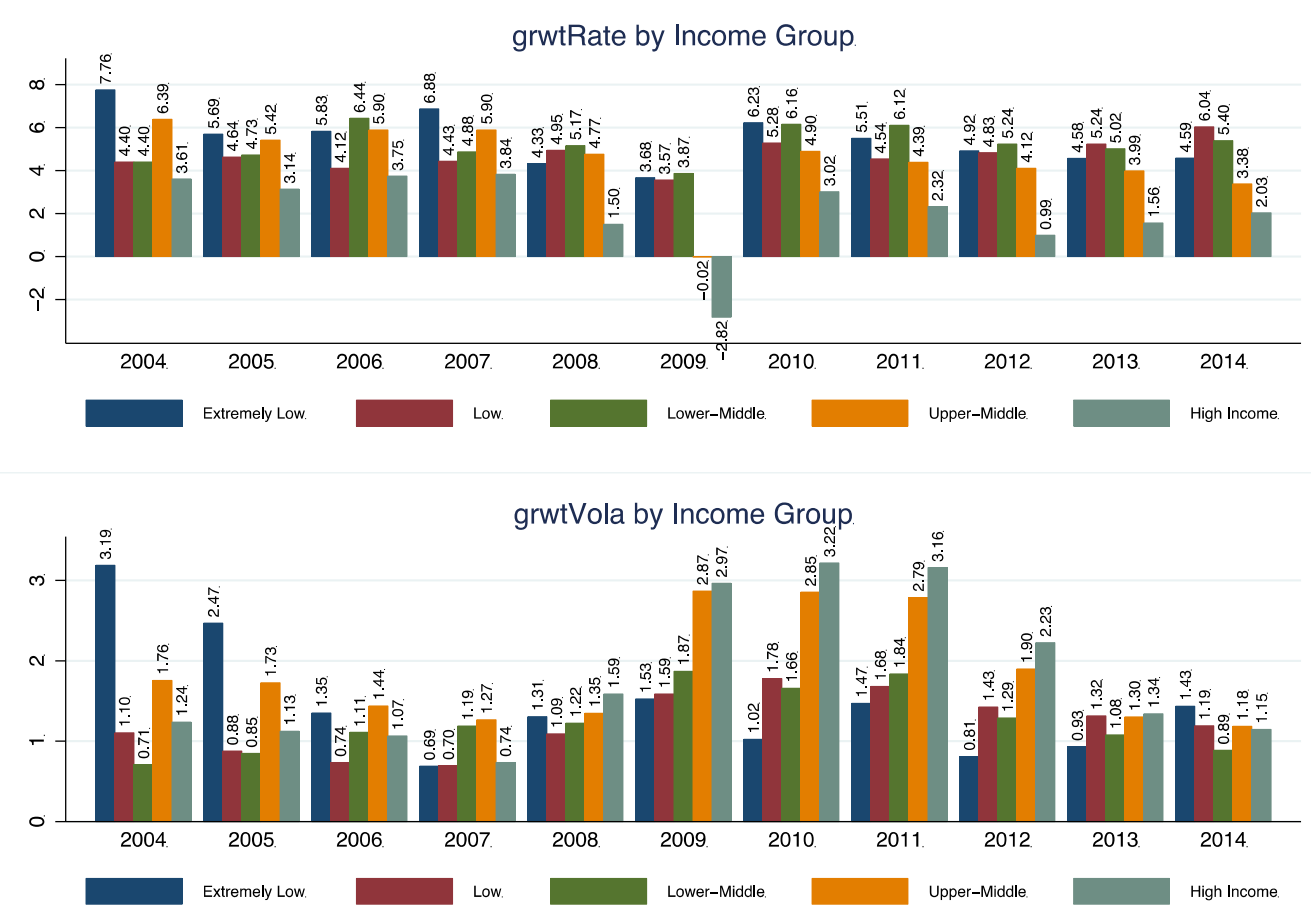

Source: Authors’ estimates.

By and large, greater flexibility of adjustment to external and domestic shocks is likely to help countries sustain growth. More formally, we need to estimate the relationship between flexibility and various factors, including institutions and economic fundamentals. This should allow us to analyse the factors accounting for adjustment of countries to shocks in terms of growth and volatility. The main variables are the following:

Shocks: Global growth shocks (globGrwt); Global oil prices [WTI crude as a proxy] (globOilp); Global financial risk tolerance and volatility [VIX as a proxy] (globFVol); Wars and civil conflicts (warConfl); Natural-disaster deaths (disaster); Growth spillovers emanating from trade partners (spillOvr). 
Institutions: Financial openness (finaOpen); Exchange rate stability (exrStabl); Political stability (polStabl); Political polarization (polPolar); Checks and balance (chknBalc); Rule of law (ruleoLaw); Economic freedom (econFree)

Fundamentals: Manufacturing output (manufOut); Foreign reserves ( $f x$ Reserv); Working-age population (wkAgePop); Schooling (eduSchlg)

While the list of controls is not exhaustive, these variables cover the basis for growth and volatility adjustment, and serve the purpose of our study. Our analysis proceeds by:

(a) Studying the natural patterns of growth and volatility adjustment to shocks in the window of the corresponding shock, focusing on the difference between pre-2008 and the post-2008 periods, comparing middle-income countries and other income groups.

(b) Estimating GDP growth and volatility adjustment - i.e. dependent variables - on a set of domestic and external macroeconomic shocks, and then mapping the estimates and residuals from the growth and volatility estimation to country's institutions and fundamentals;

\subsection{Constructing Growth-Shock Spillovers from Trade Partners}

Most of our control variables, shocks, institutions, and fundamentals are readily available for the regression analysis. We construct an additional variable, growth spillovers emanating from trade partners (spillOvr), from GDP growth and bilateral trade data. Our data are drawn from the real GDP growth and forecasts from IMF World Economic Outlook database based on semi-annual forecasts since 1990. To construct the growth spillover, spillOvr, 
(1) We use 2-years historical data and 6-years forecast data of real GDP growth, made available in World Economic Outlook database (series: ngdprpch). Historical data are updated on a continual basis, as more information becomes available, and structural breaks in the data are often adjusted to produce smooth series with the use of splicing and other techniques. These IMF staff estimates continue to serve as proxies for historical series when complete information is unavailable. As a result, WEO data can differ from other official data sources, including the IMF International Financial Statistics;

(2) We regress real-time 1-period-ahead percent forecast errors for real GDP growth from WEO database in each country - i.e. the gap at time $t$ of the growth rate of country $q$ form the WEO projection on a set of country and period fixed effects;

(3) We take the estimated residual, $\boldsymbol{e}_{q, t}$, from the above regression to capture innovations in real GDP growth orthogonal to professional forecasts and unobserved country and period fixed effects; the residual is a measure of unanticipated growth shocks.

Denoting the growth shock in source country or trade partner $q$ as $\boldsymbol{e}_{\boldsymbol{q}, t}$, measured in percent, we aggregate across countries using bilateral trade as a measure of interdependence

(2) $\quad$ spillOvr $r_{i, t}=\sum_{q \neq i} \frac{W_{i q, B}}{W_{q, B}} \times\left\{e_{q, t} \times Y_{q, t-1}\right\}$

where $\frac{W_{i q, B}}{W_{q, B}}$ is a weight of independence between source country or trade partner $q$ and recipient country or country of interest $i$, scaled by the share of i's trade in source country q's total trade. Essentially, we employ a certain factor of trade that translates, directly or indirectly, into bilateral growth spillovers with other countries, which 
influence the growth adjustment in those countries. We explore scaling by export dependence - i.e. higher growth of importing country trade partner $q$ generates greater demand for i’s output - in our main setup, and also import dependence.

Real GDP growth and forecasts come from IMF World Economic Outlook database based on semi-annual forecasts since 1990. We estimate impulse responses for 3 semi-annual horizons, starting in the $1^{\text {st }}$ half of 2004 . We use the maximum horizon $H=2$ and estimate equations for 0 to 2 periods ahead, with maximum lags $m$ $=2$. Across countries, the average standard deviation of $\frac{s p i l l O v r_{i, t}}{Y_{i, t-1}} \times 100$ is .642 . The average size of these shocks ranges from -3.3 for Hong Kong, China, to -.21 for the U.S., to .18 for Uruguay. The correlation of shock series varies across countries and trade partners. Countries sharing similar key trading partners tend to have more correlated shock series.

\section{Empirical Results}

In this section, we report and discuss the main findings which emerge from our empirical analysis.

\subsection{Patterns of data}

From an initial sample of more than 140 countries, combining the variables and dealing with missing values provide us a final sample of 80 countries, covering 2004 to 2014. Figure 5, which shows the scatter plot of GDP growth and volatility, suggests that there is no clear cluster of growth and volatility pattern based on country-income classifications. To learn more about the natural patterns of data, Figure 6 reports the summary statistics of variables. We pursue a number of different approaches to better understand patterns of data. A couple of key questions emerge. With respect to growthshock-institution-fundamental associations, do the country observations cluster around 
the designated country-income classification? In the presence of multicollinearity among controls of growth adjustment estimation, which variables - e.g. shocks, institutions, fundamentals - explain much of the flexibility of growth adjustment?

Figure 5. GDP Growth and Volatility, 2004-2014.

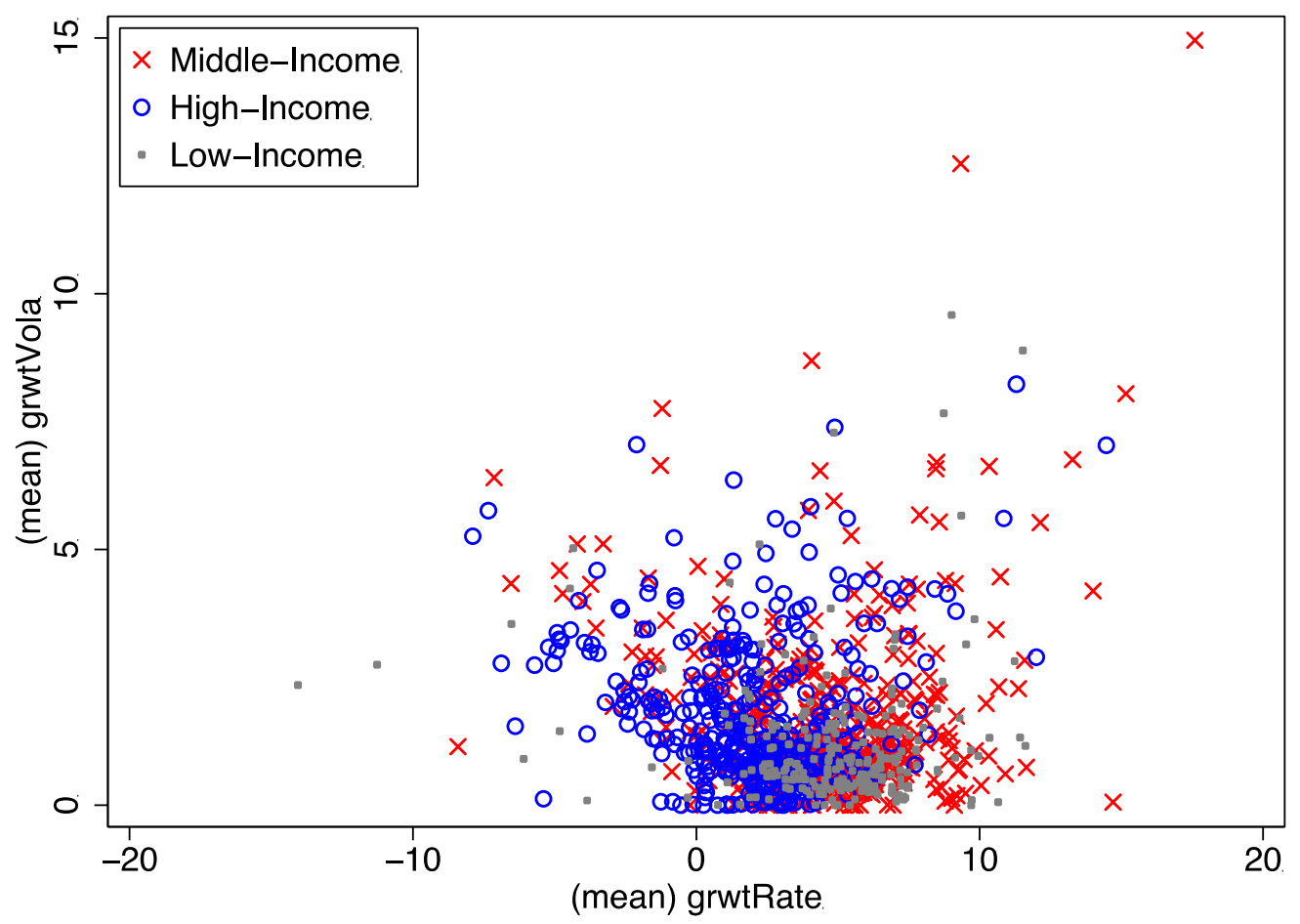

Source: Authors’ estimates. 
Figure 6. Summary Statistics: Means and Standard Deviations.

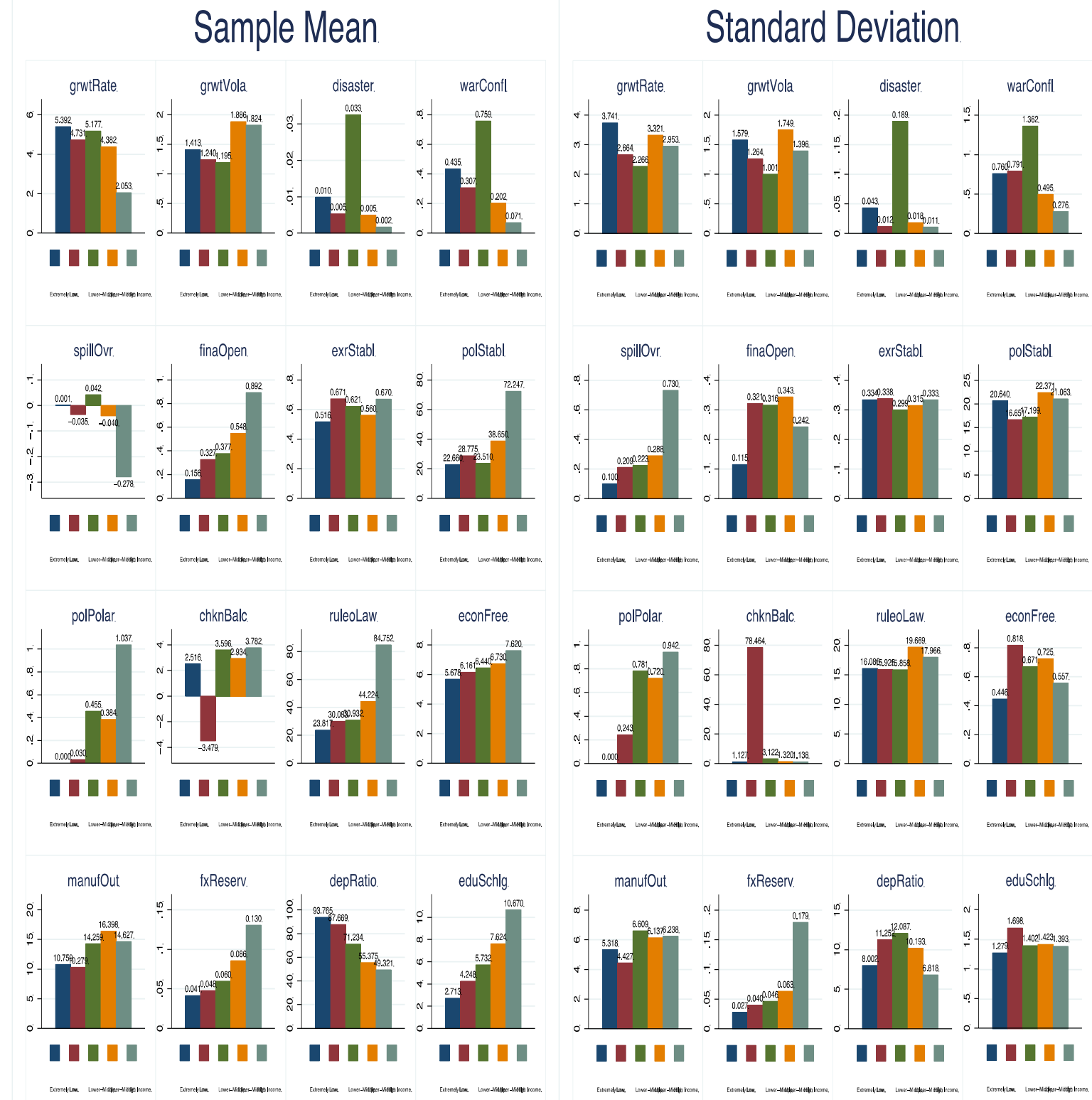

Source: Authors’ estimates.

Looking the correlations among the variables in Figure 7, several notable patterns emerge. Growth of real GDP is correlated with political stability and education attainment in both pre-2008 and post-2008 periods. In the aftermath of the global 
financial crisis, GDP growth has become more correlated with financial openness, exchange rate stability, political polarization, and old-age dependency ratio.

Figure 7. Correlation of Variables.

\section{Correlations, Pre-2008}

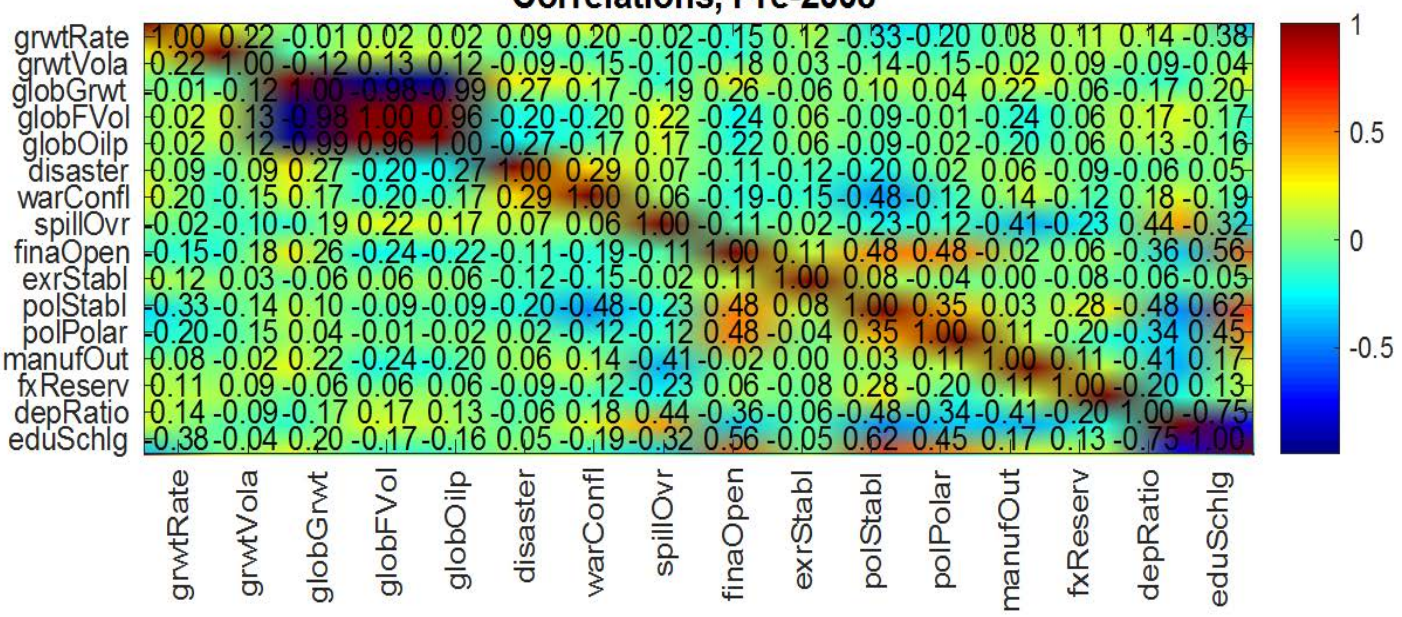

\section{Correlations, Post-2008}

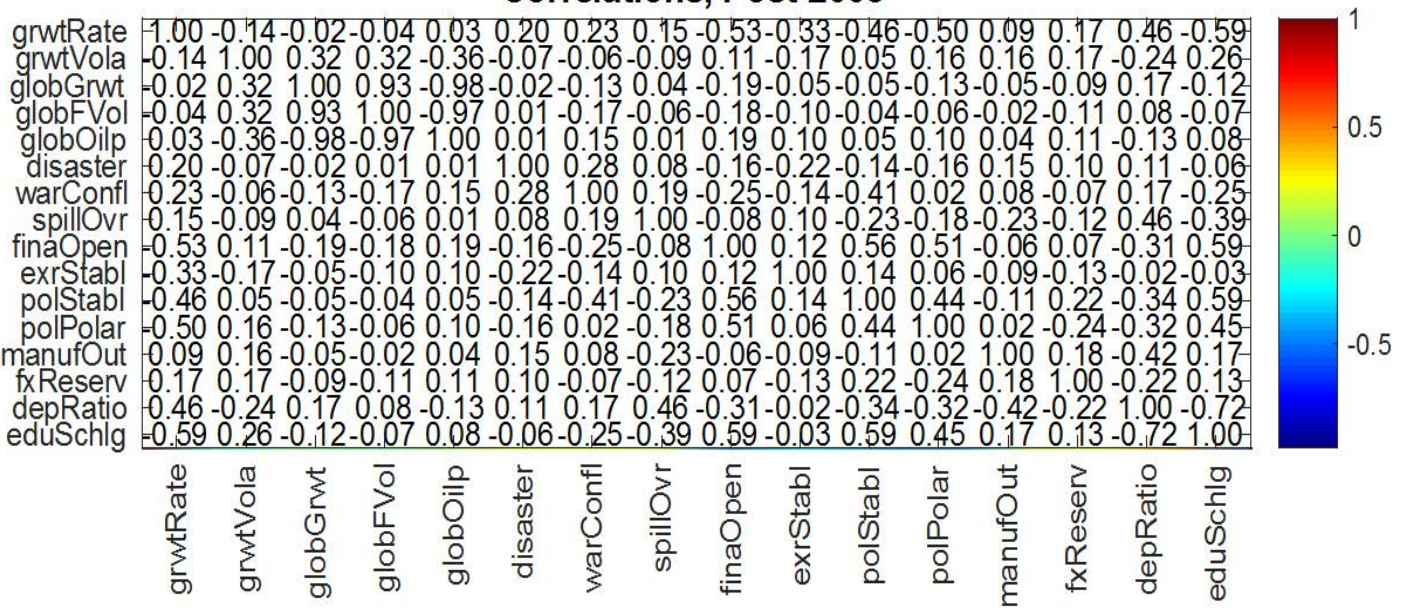

Source: Authors' estimates. 
Volatility of GDP growth is correlated with global growth, global financial volatility, and global oil prices in the post-2008 period. Global growth is correlated with global financial volatility and global oil prices. Wars and conflicts are correlated with political stability in both pre- and post-2008 periods. Growth spillovers are correlated with manufacturing output in the pre-2008 period, and with dependency ratio and education attainment in the post-2008 period. Financial openness is correlated with political stability, political polarization, dependency ratio, and education attainment in the pre- and post-2008 periods. Political stability is correlated with political polarization, dependency ratio, and education attainment in both pre- and post-2008 periods. Political polarization is correlated with dependency ratio and education attainment in both pre- and post-2008 periods. Manufacturing output is correlated with dependency ratio in both pre- and post-2008 periods. Dependency ratio is correlated with education attainment in both pre- and post-2008 periods. The patterns of correlations suggest that most variables are corrrelated in the Pre- and Post-2008 periods.

An alternative approach to study the data patterns is to ask how many country groups would fit with the current set of country observations. Based on the multidimensional scaling, shown in Figure 8, it is not clear how the associations of growth-shock-institution-fundamental can help classify countries into distinct groups in the pre-2008 and in the post-2008 period. The evidence seems to suggest that, in terms of growth-shock-institution-fundamental associations, the country observations do not cluster around the designated country-income classification. That is, there is nothing unique in this respect about middle income countries or other income groups of countries. 
Figure 8. Multidimensional Scaling of Countries, Pre- and Post-2008.

Multidimensional Scaling, Pre-2008
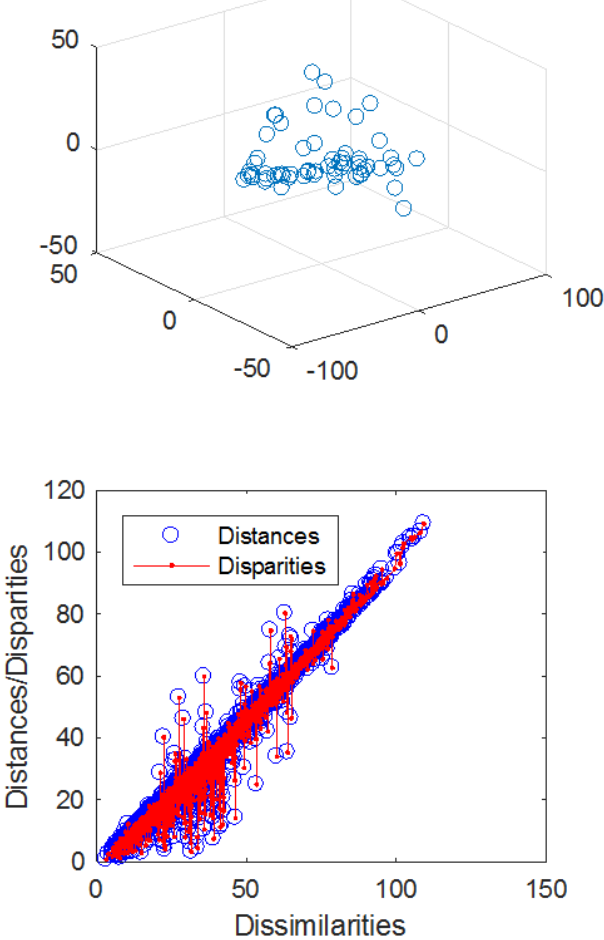

Source: Authors’ estimates.
Multidimensional Scaling, Post-2008
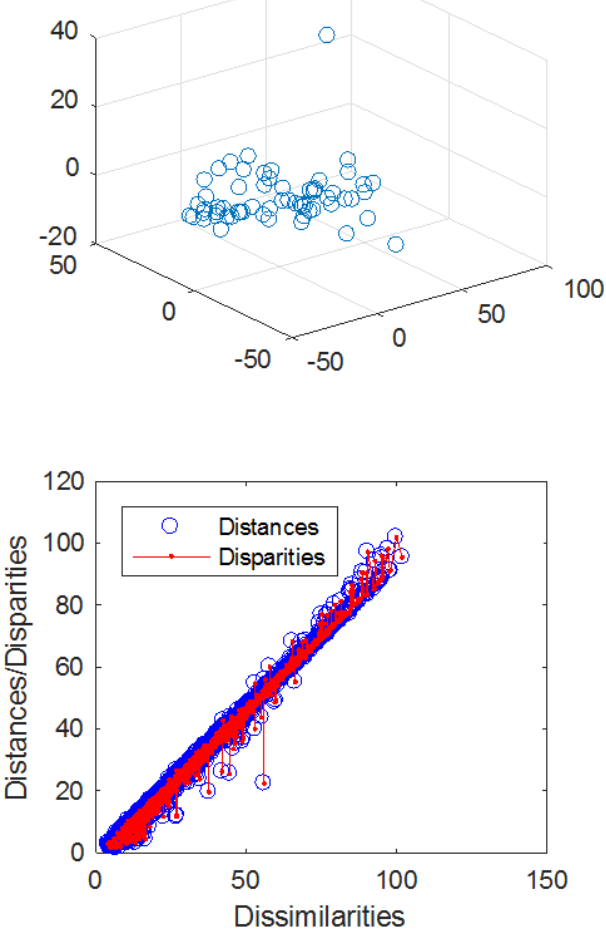
Figure 9 provides an alternative way to cluster the country data. The figure shows clustering analysis of countries based on observed growth, volatility, shocks, institutions, and fundamentals. The alphabetically ordered groups are based on the designated country-income classification, while the numerically ordered groups are based on the clustering analysis. Essentially, the analysis contrasts the designated country-income classification with the patterns of country observations based on all the variables in our sample. In the pre-2008 period, it is not clear if the income grouping fits with a matrix of variables. For example, based on the macroeconomic characteristics - i.e. growth-shock-institution-fundamental - several middle-income countries can be grouped with the high-income countries. Similarly, in the post-2008 period, the clustering analysis indicates that income classification does not translate into the similar associations of growth, volatility, institutions, and fundamentals of countries in the same designated groupings. A notable result is that global and country specific shocks seem to be driving the differences across countries. 
Figure 9. Clusters of Country Observations, Pre-2008 and Post- 2008.
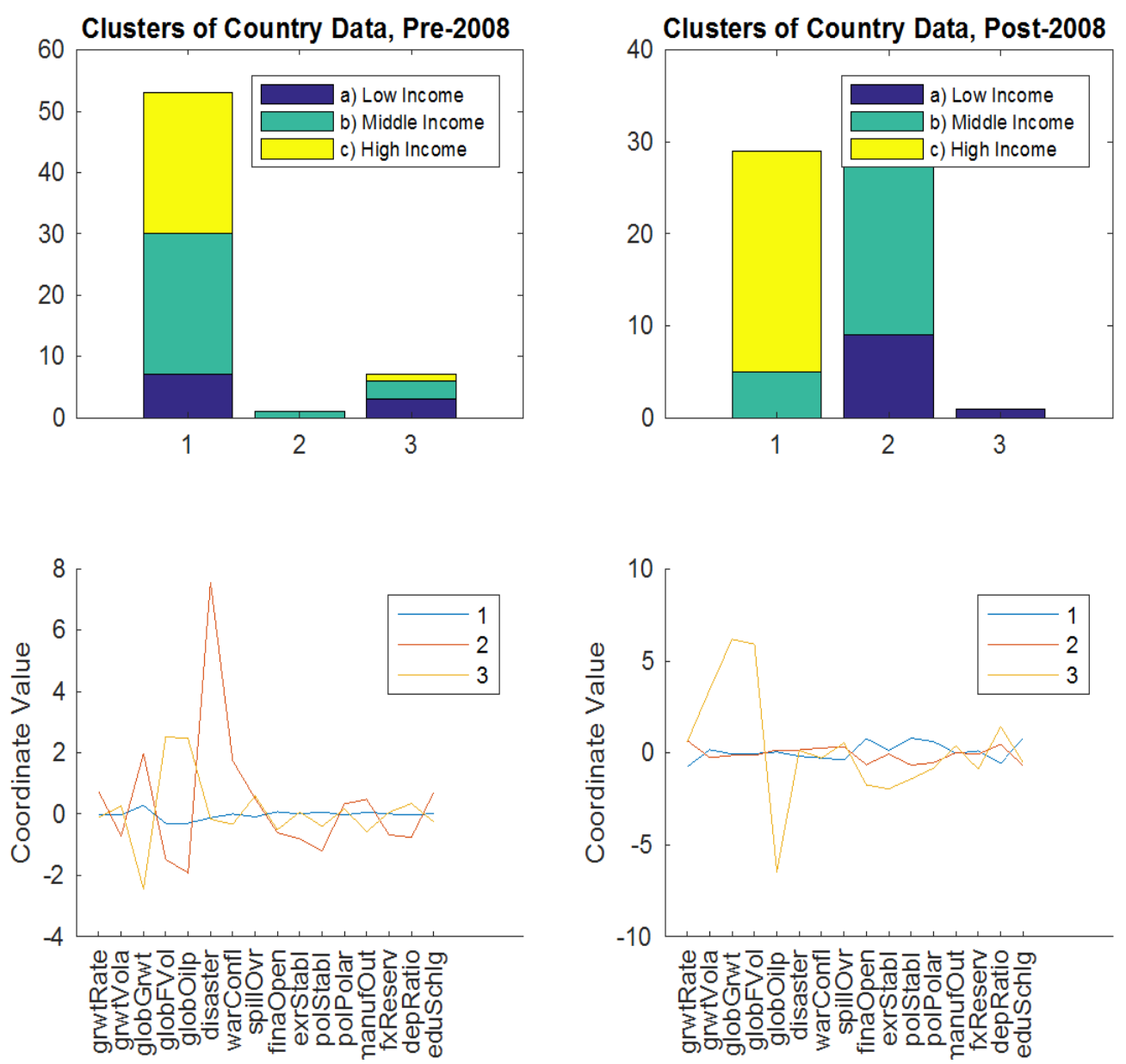

Source: Authors’ estimates.

Next we look at which variables - i.e. shocks, institutions, and fundamentals explain much of the movements of GDP growth and volatility in the presence of multicollinearity among control variables. Following Hastie, Tibshirani, and Friedman (2008), the least absolute shrinkage and selection operator (LASSO) estimate is defined by

$$
\begin{aligned}
& \hat{\beta}^{\text {lasso }}=\underset{\beta}{\arg \min } \sum_{i t=1}^{N T}\left(y_{i t}-\beta_{0}-\sum_{j=1}^{p} x_{i t, j} \beta_{j}\right)^{2} \\
& \text { subject to } \sum_{j=1}^{p}\left|\beta_{j}\right| \leq z
\end{aligned}
$$


The equivalent Lagrangian form is

$$
\hat{\beta}^{\text {lasso }}=\underset{\beta}{\arg \min }\left\{\sum_{i t=1}^{N T}\left(y_{i t}-\beta_{0}-\sum_{j=1}^{p} x_{i t, j} \beta_{j}\right)^{2}+\lambda \sum_{j=1}^{p}\left|\beta_{j}\right|\right\}
$$

where, $\lambda$ is the shrinkage (regularization) factor, $y_{i t}$ the dependent variable (GDP growth), and $\boldsymbol{x}_{i t}$ the vector of explanatory variables (macroeconomic controls). Note that unlike the fixed-effect estimation, this setup does not directly account for countryspecific fixed effects

Figure 10 provides the trace plots of coefficient fit by LASSO for middleincome and high-income countries, respectively. For middle-income countries, globFVol, warConfl, and GFC are the most significant in accounting for the growth adjustment, but none help to explain volatility adjustment. For high-income countries, globFVol, spillOvr, finaOpen, exrStabl, fxReserv, depRatio, and GFC are the most significant in accounting for growth adjustment, whereas globGrwt, globFVol, manufOut, fxReserv, depRatio, and GFC are the most significant in accounting for the volatility adjustment. The analysis supports the notion that the global financial crisis was a game changer, with global factors and shocks largely driving growth and volatility. 
Figure 10. Accounting for Growth and Volatility

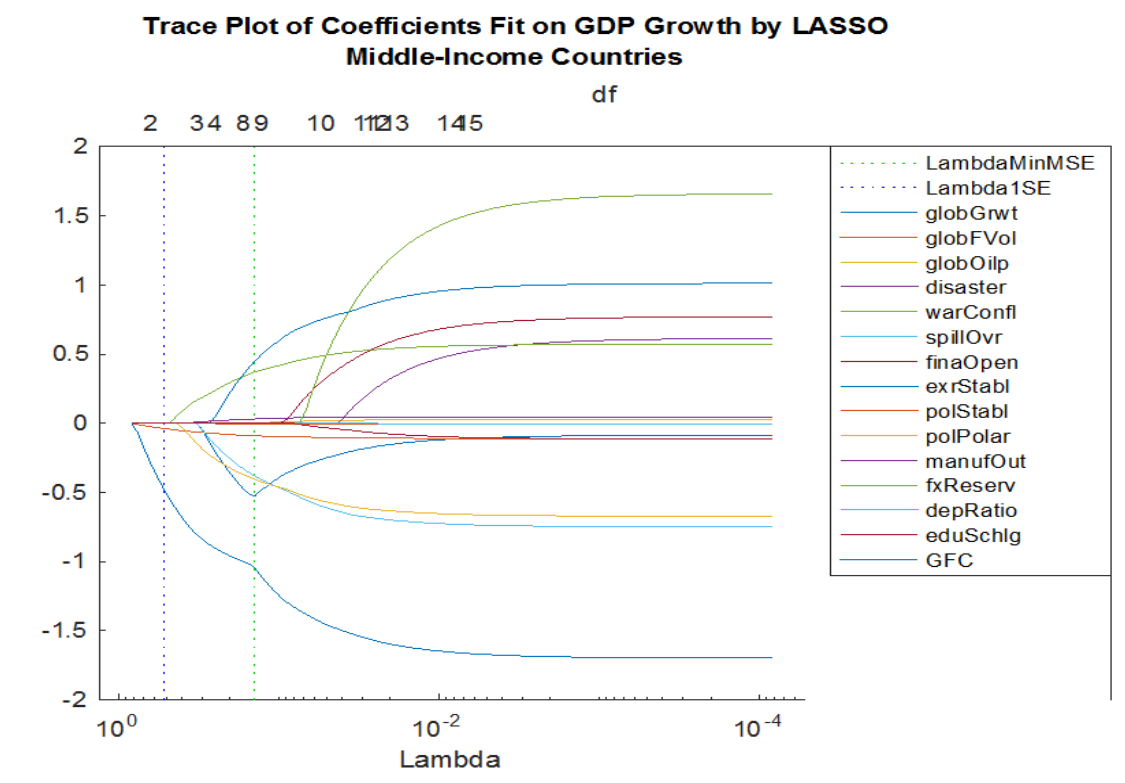

Trace Plot of Coefficients Fit on GDP Grow th by LASSO High-Income Countries

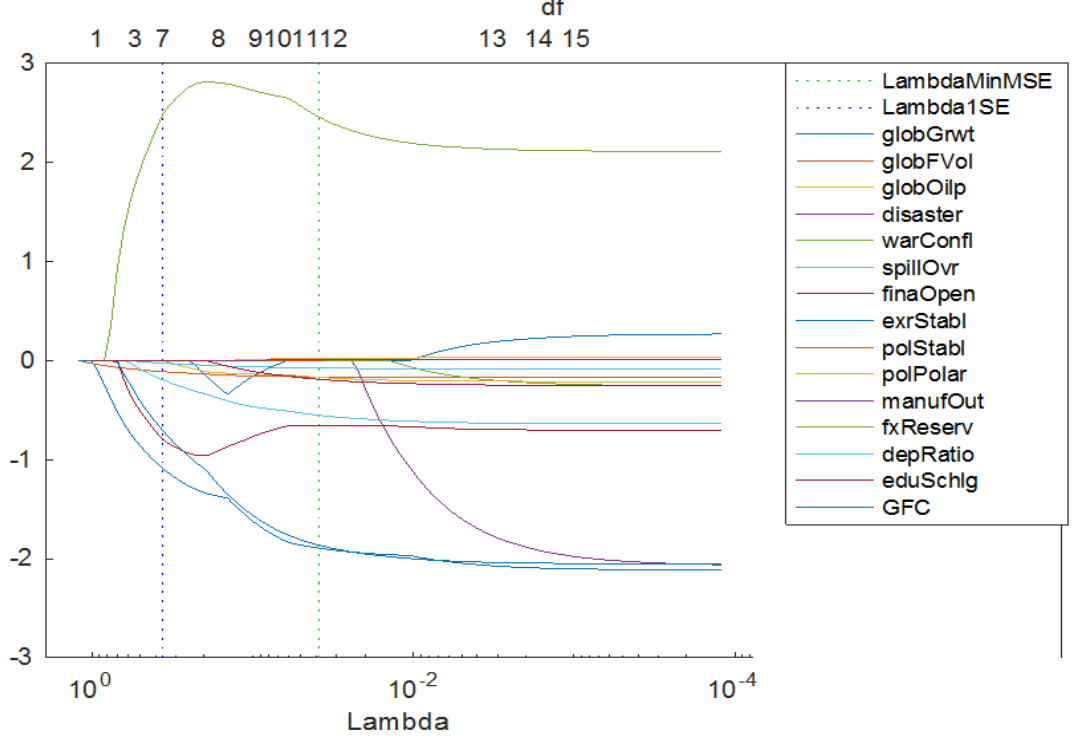


Trace Plot of Coefficients Fit on Growth Volatility by LASSO Middle-Income Countries

df

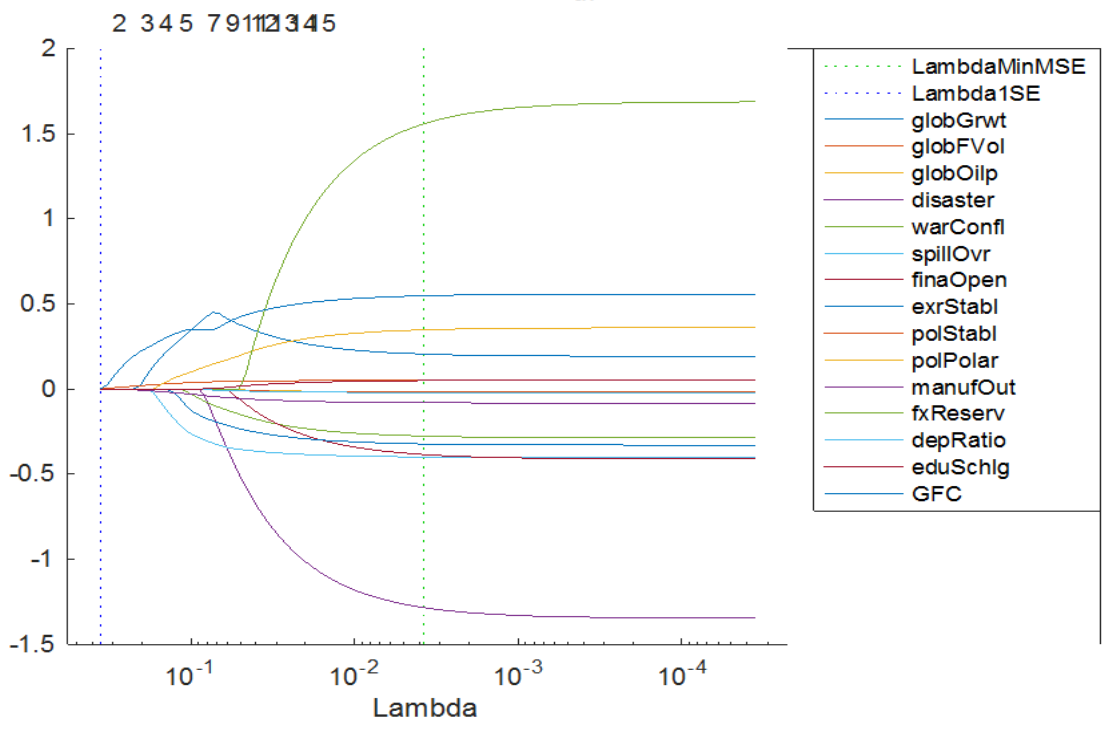

Trace Plot of Coefficients Fit on Growth Volatility by LASSO High-Income Countries

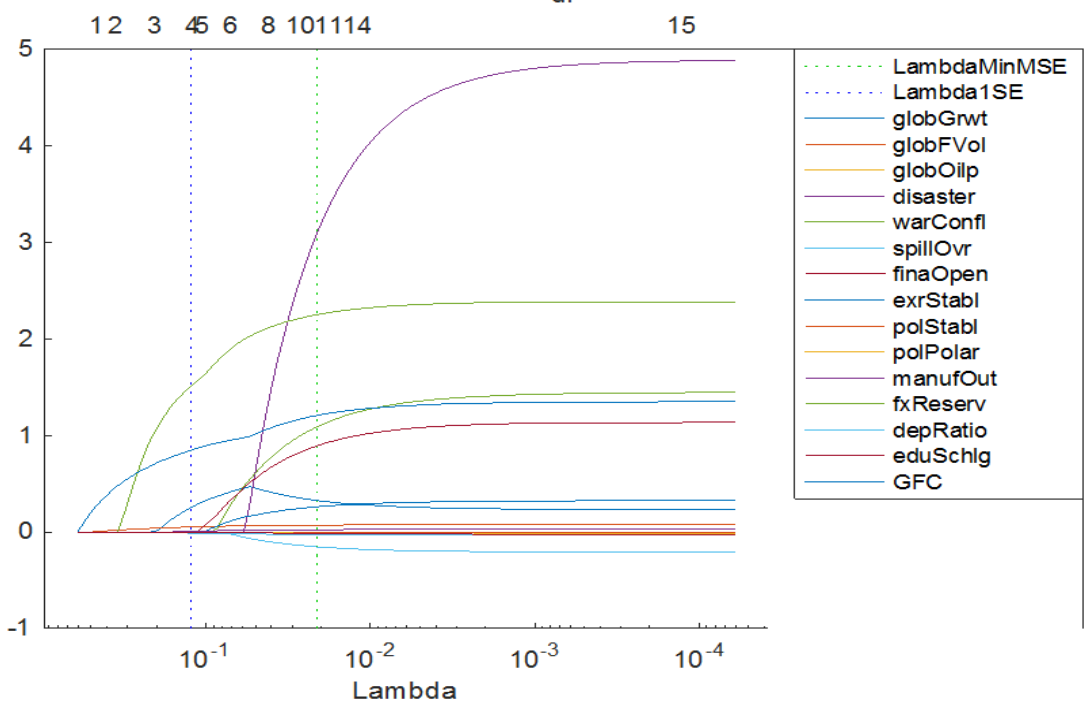

Source: Authors’ estimates. 


\subsection{Panel Estimation}

More specifically, we want to estimate the associations between the dependent variable - i.e. GDP growth and GDP volatility - and domestic and external shocks as well as GDP growth spillovers from trade partners, using direct projections from a series of regressions for different horizon, $h=0, \ldots, H$

$$
\begin{aligned}
Y_{i, t+h}-Y_{i, t+1} & =\sum_{s=1}^{m} \beta_{h s} \Delta Y_{i, t-s}+\sum_{s=1}^{m} \delta_{h s} X_{i t-s}+\alpha_{h} \frac{\text { spillOvr }_{i, t}}{Y_{i t+1}} \\
& +\phi_{h i}+\mu_{h t}+\varepsilon_{i h t}
\end{aligned}
$$

where $Y$ denotes the dependent variable (GDP growth, GDP volatility); $X$ is a vector of controls (domestic and external shocks); $\phi$ and $\boldsymbol{\mu}$ are horizon-specific country and time fixed effects; spillOvr is the measure of growth spillovers emanating from trade partners; $i$ stands for country; and $t$ stands for time period. Impulse response for $H$ periods is constructed from a sequence of estimated $\left[\alpha_{h}\right]_{h=0}^{H}$.

Table 1 reports the GDP growth and volatility accounted for by shocks and growth spillovers emanating from trade partners - i.e. top importing countries. The coefficient estimates are reported with standard errors in parentheses. The first two columns report the growth estimates for the whole sample, split into pre-2008 and post2008 periods, while the following two columns report estimates for the middle income sample. The estimation results suggest that global growth (+), global financial volatility $(+)$, and global oil prices (-) are associated with country growth in the pre-2008 period, while global growth (+), global financial volatility (-), and global oil prices (+) are associated with country growth in the post-2008 period. These qualitative results are applicable to the whole sample and the middle-income sample. The overall explanatory power is a quarter to a third in this set of estimations. 
The second half of Table 1 reports the growth volatility estimation. The coefficient estimates are reported with standard errors in parentheses. The estimation results suggest that global growth (-), global financial volatility (-), global oil prices $(+)$, and natural disaster $(+)$ are associated with growth volatility in the pre-2008 period, while global growth (-), global financial volatility (+), and global oil prices (-) are associated with growth volatility in the post-2008 period. For the middle-income sample, the estimation results are qualitatively similar. The overall explanatory variable is about a tenth to a quarter in this set of estimations.

Focusing on the associations between GDP growth and growth spillovers from trade partners, it is useful to look at the impulse responses of growth over a number of time periods. Table 2 reports the average growth spillovers from trade partners' growth shocks over three periods, $\frac{1}{3} \sum_{h} \alpha_{h} ; \boldsymbol{h}=0,1,2$, with standard errors in parentheses. The calculation is done using different trade weights - all top trade partners in the first column, top importers in the second column, and top exporters in the third column. The results suggest that growth shocks emanating from trade partners are associated with growth spillovers $(+)$ in the pre-2008 period, but become much less significant in the post-2008 period. 
Table 1. Growth, Volatility, and Shocks, 2004-2014.

\begin{tabular}{|c|c|c|c|c|c|c|c|c|}
\hline \multirow{2}{*}{$\begin{array}{r}\text { Y } \\
\text { Sample }\end{array}$} & \multicolumn{5}{|c|}{ GDP Growth Level } & \multicolumn{5}{c|}{ GDP Growth Volatility } \\
\cline { 2 - 9 } X: & \multicolumn{2}{|c|}{ Whole Sample } & \multicolumn{1}{c|}{ Middle-Income Countries } & \multicolumn{2}{c|}{ Whole Sample } & \multicolumn{2}{c|}{ Middle-Income Countries } \\
\cline { 2 - 9 } & Pre-2008 & Post-2008 & Pre-2008 & Post-2008 & Pre-2008 & Post-2008 & Pre-2008 & Post-2008 \\
\hline D.Y(t-1) & -.017 & -.034 & -.009 & -.036 & .289 & .213 & .255 & .197 \\
& $(.023)$ & $(.025)$ & $(.034)$ & $(.037)$ & $(.036)^{* * *}$ & $(.029)^{* * *}$ & $(.049)^{* * *}$ & $(.045)^{* * *}$ \\
\hline D.Y(t-2) & -.305 & -.342 & -.359 & -.419 & -.036 & -.082 & -.027 & -.092 \\
& $(.025)^{* * *}$ & $(.027)^{* * *}$ & $(.036)^{* * *}$ & $(.041)^{* * *}$ & $(.022)$ & $(.028)^{* *}$ & $(.029)$ & $(.044)^{*}$ \\
\hline globGrwt(t) & 1.126 & 2.080 & 1.150 & 1.698 & -1.171 & -.141 & -.992 & -.136 \\
& $(.276)^{* * *}$ & $(.238)^{* * *}$ & $(.475)^{*}$ & $(.388)^{* * *}$ & $(.244)^{* * *}$ & $(.068)^{*}$ & $(.394)^{*}$ & $(.101)$ \\
\hline globFVol(t) & .043 & -.138 & .040 & -.144 & -.022 & .020 & -.018 & .025 \\
& $(.011)^{* * *}$ & $(.017)^{* * *}$ & $(.019)^{*}$ & $(.027)^{* * *}$ & $(.006)^{* * *}$ & $(.005)^{* * *}$ & $(.009)^{*}$ & $(.007)^{* * *}$ \\
\hline globOilp(t) & -.041 & .091 & -.027 & .096 & .007 & -.016 & .007 & -.014 \\
& $(.005)^{* * *}$ & $(.010)^{* * *}$ & $(.008)^{* * *}$ & $(.016)^{* * *}$ & $(.002)^{* * *}$ & $(.003)^{* * *}$ & $(.003)^{*}$ & $(.004)^{* *}$ \\
\hline disaster(t) & -.034 & 2.619 & -.064 & -3.823 & 1.180 & .724 & .290 & .984 \\
& $(.567)$ & $(6.617)$ & $(.664)$ & $(12.231)$ & $(.523)^{*}$ & $(1.970)$ & $(.687)$ & $(3.343)$ \\
\hline warConfl(t) & -.007 & .024 & -.094 & .079 & .001 & .007 & .053 & -.001 \\
& $(.060)$ & $(.096)$ & $(.083)$ & $(.118)$ & $(.027)$ & $(.029)$ & $(.035)$ & $(.032)$ \\
\hline spillOvr(t) & .102 & -.127 & .158 & -.355 & .000 & .004 & -.035 & -.002 \\
& $(.060)$ & $(.093)$ & $(.156)$ & $(.292)$ & $(.026)$ & $(.028)$ & $(.069)$ & $(.080)$ \\
\hline time trend & .219 & -.294 & .160 & -.349 & -.196 & .009 & -.190 & .009 \\
& $(.043)^{* * *}$ & $(.032)^{* * *}$ & $(.074)^{*}$ & $(.050)^{* * *}$ & $(.040)^{* * *}$ & $(.010)$ & $(.065)^{* *}$ & $(.014)$ \\
\hline R-sq. & .268 & .316 & .264 & .358 & .173 & .226 & .130 & .252 \\
Obs & 761 & 1,104 & 347 & 472 & 671 & 1,104 & 309 & 473 \\
\hline
\end{tabular}

Source: Authors' estimates. 
Table 2. Growth Spillovers from Trade Partners, 2004-2014.

This table reports the average growth spillovers from trade partners' growth shocks over three half-yearly (six quarterly) periods,

$\frac{1}{3} \sum_{h} \alpha_{h} ; h=0,1,2$. Standard errors are in parentheses.

\begin{tabular}{|c|c|c|c|c|c|c|c|}
\hline \multirow{2}{*}{\multicolumn{2}{|c|}{$\begin{array}{l}\text { Average Growth Spillovers } \\
\text { over six quarterly periods }\end{array}$}} & \multicolumn{6}{|c|}{ Trade Partners } \\
\hline & & \multicolumn{2}{|c|}{ Importers and Exporters } & \multicolumn{2}{|c|}{ Importers } & \multicolumn{2}{|c|}{ Exporters } \\
\hline Sample & estimates & All & 10 Largest & All & 10 Largest & All & 10 Largest \\
\hline \multirow[t]{2}{*}{$2004-2014$} & coefficient & 0.024 & 0.057 & 0.051 & 0.114 & 0.029 & 0.085 \\
\hline & std. err. & 0.013 & 0.021 & 0.026 & 0.040 & 0.022 & 0.037 \\
\hline \multirow[t]{2}{*}{ Pre-2008 } & coefficient & 0.000 & 0.047 & 0.036 & 0.102 & -0.026 & 0.068 \\
\hline & std. err. & 0.016 & 0.026 & 0.031 & 0.051 & 0.027 & 0.046 \\
\hline \multirow[t]{2}{*}{ Post-2008 } & coefficient & 0.010 & 0.033 & -0.012 & 0.063 & 0.034 & 0.049 \\
\hline & std. err. & 0.020 & 0.029 & 0.040 & 0.055 & 0.033 & 0.051 \\
\hline
\end{tabular}

Source: Authors' estimates. 
To identify the conditions that drive faster and smoother adjustment of growth to shocks for the middle-income countries in the 2004-2014 period, we correlate the estimated residuals of growth and volatility, controlling for domestic and external shocks, with institutions and economic fundamentals, measured by their coefficient of variation over five-year periods. Figure 11 shows that shock-adjusted growth is positively associated with higher education attainment, manufacturing output, and exchange rate stability, while the shock-adjusted volatility is positively associated with higher exchange rate stability and polarization, and lower education attainment.

Focusing on the most significant variables, Figure 12 plots the data between two sub-periods for middle income countries. The scatterplots suggest that economic fundamentals such as manufacturing output to GDP ratio and education attainment showed persistent pattern over the years, while institutional factors such as exchange rate stability and political polarization changed significantly between 2003-07 and 2010-14 across the middle-income countries. Understanding the country-specific persistence and evolution over time of these variables is therefore useful in accounting for the adjustment of GDP growth and volatility. 
Figure 11. Correlatons of Shock-Adjusted Growth and Volatility with

Fundamental and Institutional Factors in Middle-Income Countries.
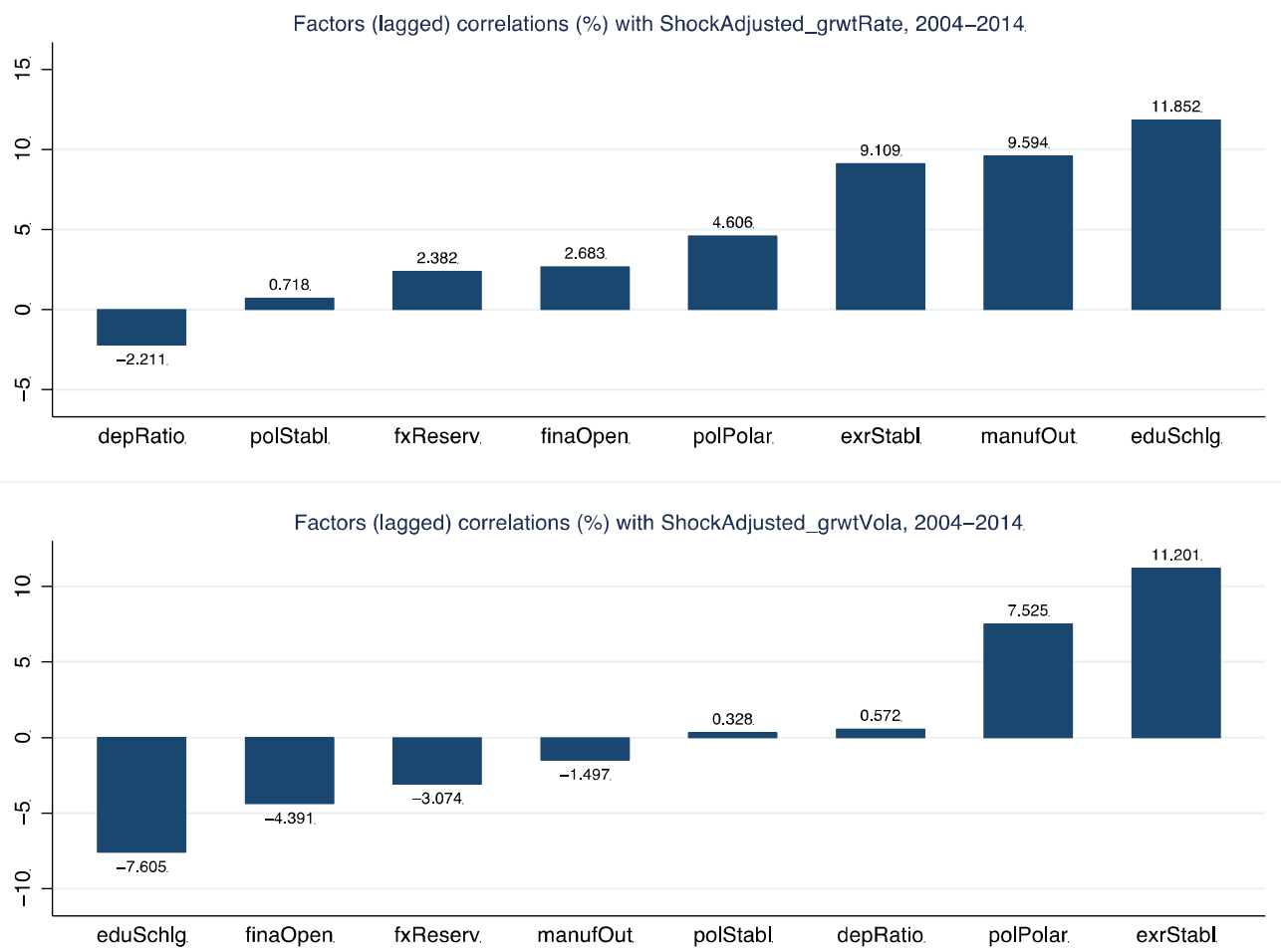

Source: Authors’ estimates. 
Figure 12. Scatterplot of Selected Institutions and Fundamental Variables for Middle-Income Countries.
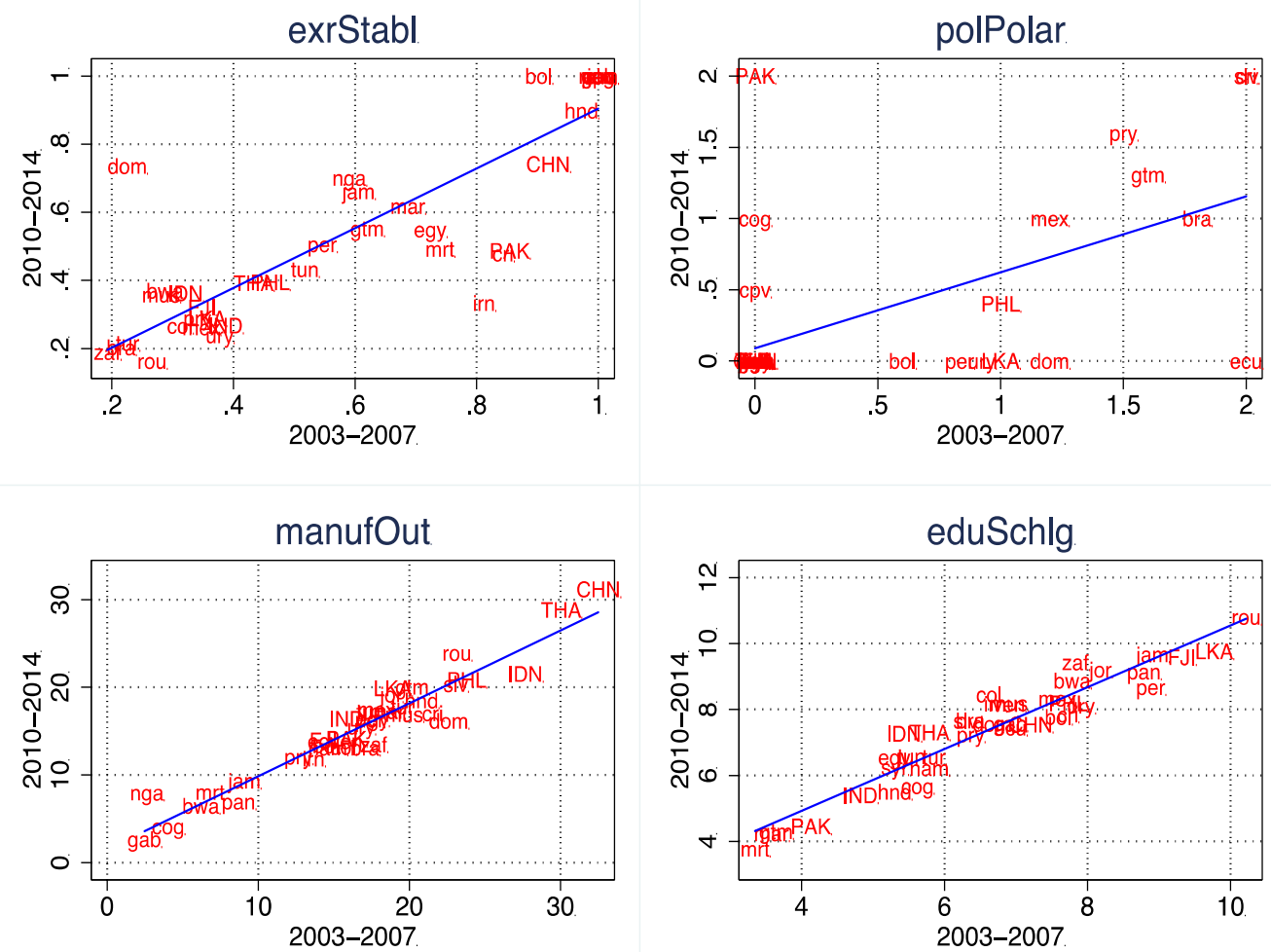

Source: Authors’ estimates.

\section{Concluding Observations}

In this paper, we examine how economic growth and growth volatility are associated with internal and external shocks, as well as shock spillovers from trade partners, before and after the global financial crisis, taking into account country-specific economic institutions and fundamentals. Flexibility of growth adjustment is an issue of high and growing importance, especially against the background of post-crisis global growth slowdown and heightened political and policy uncertainty. The vulnerability of middle income countries to shocks is an interesting issue since these countries are typically more integrated into the world economy but, unlike most high income countries, often lack well-established policies and institutions to cope with shocks. 
Our analysis examines and compares the role of institutions and fundamentals on the adjustment of growth and volatility to shocks in the pre-crisis and post-crisis periods. Empirical analysis of panel data of high-income, middle-income, and lowincome countries over 2004-2014 shows that the associations of growth, volatility, shocks, institutions, and economic fundamentals have changed in important ways after the crisis. More specifically, we find that GDP growth across all income groups of countries have become more dependent on the external factors, including global growth, global oil prices, and global financial volatility. In addition, despite the slowdown of global trade after the crisis, there is evidence that growth spillovers from trade partners have economically significant effects on country's growth. There is nothing unique about the exposure of middle income countries to such global shocks.

A country's response and adjustment to shocks depends on several factors - age dependency ratio and foreign reserves, to name just two. After accounting for the effects from global shocks, for middle income countries we identify some factors that facilitate adjustment to shocks, in terms of growth and volatility. Higher education attainment, higher manufacturing output in GDP, and higher exchange rate stability increase economic growth. Lower political polarization, higher exchange rate flexibility, and higher education attainment reduce the volatility of economic growth. Therefore, overall, our cross-country findings suggest that countries can cope with shocks better in the short to medium term by appropriately using flexible policy tools - for instance, greater exchange rate flexibility help reduce growth volatility - as well as maintaining solid long-term fundamentals - for instance, higher education and lower political polarization help reduce growth volatility. 


\section{References}

Acemoglu, Daron, Simon Johnson, James A. Robinson, and Yunyong Thaicharoen. 2003. "Institutional Causes, Macroeconomic Symptoms: Volatility, Crises and Growth.” Journal of Monetary Economics 50 (1) :49-123.

Aghion, P., P. Bacchetta, R. Rancier, K. Rogoff (2009) "Exchange rate volatility productivity growth: The role of financial development" Journal of Monetary Economics 56: 494-513.

Aizenman, J., Chinn, M. D., and Ito, H. 2013. The "Impossible Trinity” Hypothesis in an Era of Global Imbalances: Measurement and Testing. Review of International Economics, 21: 447-458.

2011. "Surfing the waves of globalization: Asia and financial globalization in the context of the trilemma," Journal of the Japanese and International Economies, Elsevier, vol. 25(3), pages 290-320, September.

Aizenman, Joshua, and Jaewoo Lee. "International reserves: precautionary versus mercantilist views, theory and evidence." Open Economies Review18.2 (2007): 191-214.

Aizenman J., S. Edwards and D. Riera-Crichton (2012). “Adjustment patterns to commodity terms of trade shocks: the role of exchange rate and international reserves policies,” Journal of International Money and Finance, 31, 8: 19902016.

Aizenman, J. and D. Riera-Crichton (2014) Commodity Prices and Macroeconomic Policy, Rodrigo Caputo, Roberto Chang, Claudio Raddatz (eds). Central Banking, Analysis, and Economic Policies, volume 20 [and NBER WP \# 20646].

Aizenman, Joshua, and Nancy Marion. 1993. "Policy Uncertainty, Persistence and Growth." Review of International Economics 1(9):145-63. "Volatility and Investment” Economica, Vol. 66 (1999): 157-179.

Barro, Robert J. and Lee, Jong Wha. 2013. A new data set of educational attainment in the world, 1950-2010, Journal of Development Economics, Volume 104, Pages 184-198.

Beck, Thorsten, George Clarke, Alberto Groff, Philip Keefer, and Patrick Walsh, 2001. "New tools in comparative political economy: The Database of Political Institutions." 15:1, 165-176 (September), World Bank Economic Review.

Broda, Christian, 2004, "Terms of Trade and Exchange Rate Regimes in Developing Countries," Journal of International Economics, 63(1), pp. 31-58.

Caballero, Ricardo J. 1991. "On the Sign of the Investment-Uncertainty Relationship.” American Economic Review 81 (1) :279--88.

Calvo, Guillermo A. (1998). "Capital Flows and Capital-Market Crises: The Simple Economics of Sudden Stops". Journal of Applied Economics. 1 (1): 35-54.

Calvo, Guillermo A.; Reinhart, Carmen (2000). "When Capital Inflows Come to a Sudden Stop: Consequences and Policy Options". In Kenen, P.; Swoboda, A. Reforming the International Monetary and Financial System. Washington, DC: International Monetary Fund.

Céspedes, Luis Felipe, and Andrés Velasco, 2012,"Macroeconomic Performance During Commodity Price Booms and Busts." IMF Economic Review 60, no.4: 570-599.

Easterly, William, Roumeen Islam, and Joseph E. Stiglitz. 2000. "Shaken and Stirred: Explaining Growth Volatility.” In Boris Pleskovic and Joseph E. Stiglitz, 
eds., Annual World Bank Conference on Development Economics 2000. Washington, D.C.: World Bank.

Edwards, Sebastian, and Eduardo Levy Yeyati, 2005, "Flexible Exchange Rates as Shock Absorbers,” European Economic Review, Vol. 49, Issue 8, November, pp. 2079-05.

Eichengreen, Barry, Ricardo Hausmann, and Ugo Panizza. "Original sin: the pain, the mystery, and the road to redemption." IADB Conference "Currency and Maturity Matchmaking: Redeeming Debt from Original Sin. 2002.

Eichengreen, Barry, Poonam Gupta, and Ashoka Mody. "Sudden stops and IMFsupported programs." Financial markets volatility and performance in emerging markets. University Of Chicago Press, 2008. 219-266.

Frankel, J. A. (2011). "A Solution to Fiscal Procyclicality: the Structural Budget Institutions Pioneered by Chile," Journal Economía Chilena (The Chilean Economy), 2: 39-78, August.

Frankel, J. A. \& Vegh, Carlos A. \& Vuletin, Guillermo (2013). "On graduation from fiscal procyclicality," Journal of Development Economics, vol. 100: 32-47.

Gavin, Michael, Ricardo Hausmann, Roberto Perotti y Ernesto Talvi. (1996). Managing Fiscal Policy in Latin America and the Caribbean: Volatility, Procyclicality, and Creditworthiness, Inter-American Development Bank, Office of the Chief Economist, Working Paper 326.

Han, X. and Wei, S.J. 2015. Re-examining the Middle-Income Trap Hypothesis: What to Reject and What to Revive? Asian Development Bank.

Hastie, Trevor, Tibshirani, Robert, and Friedman, Jerome, 2009. The Elements of Statistical Learning: Data Mining, Inference, and Prediction, Second Edition, Springer-Verlag New York.

Hausmann, Ricardo and Michael Gavin. (1996) "Securing Stability and Growth in a Shock Prone Region: The Policy Challenge for Latin America." IDB, Working Paper Series; 315.

IDB (Inter-American Development Bank). (1995) Overcoming Volatility. Economic and Social Progress in Latin America. 1995 Report. Washington, D.C.: InterAmerican Development Bank.

Keefer, Philip and David Stasavage. 2003. "The Limits of Delegation: Veto Players, Central Bank Independence and the Credibility of Monetary Policy." American Political Science Review, 97, 3, 407-423.

Lucas, Robert E., Jr. Models of business cycles. New York: Basil Blackwell, 1987.

Marshall, Monty G., Keith Jaggers. 2002. Polity IV Project: Political Regime Characteristics and Transitions, 1800-2002.

Pindyck, Robert S. and Andrés Solimano (1993) "Economic Instability and Aggregate Investment", in Olivier Jean Blanchard and Stanley Fischer (eds) NBER Macroeconomic Annual: 1993, The MIT Press.

Ramey, Garey, and Valerie A. Ramey. 1995. "Cross-country Evidence on the Link between Volatility and Growth.” American Economic Review 85 (5) :1138-51.

Reinhart, Carmen M., and Kenneth S. Rogoff. This time is different: eight centuries of financial folly. Princeton university press, 2009.

Rodrik, Dani. 1999. "Where Did All the Growth Go? External Shocks, Social Conflict and Growth Collapses.” Journal of Economic Growth 4 (4):385--412. 


\section{Appendix. Data Sources}

\begin{tabular}{|c|c|c|}
\hline Variables & Description & Source \\
\hline grwtRate & Percent change of Gross Domestic Product, constant prices & $\begin{array}{l}\text { World Economic Outlook Database } \\
\text { Years covered: 1993-2015 } \\
\text { Country Coverage: } 178\end{array}$ \\
\hline grwtVola & Standard deviation (5-year) of real GDP growth & $\begin{array}{l}\text { World Economic Outlook Database } \\
\text { Years covered: 1993-2015 } \\
\text { Country Coverage: } 178\end{array}$ \\
\hline manufOut & Manufacturing, value added (\% of GDP) & $\begin{array}{l}\text { World Development Indicators } \\
\text { Years covered: } 1960-2015 \\
\text { Country Coverage: } 227\end{array}$ \\
\hline wkAgePop & Age dependency ratio (\% of working-age population) & $\begin{array}{l}\text { World Development Indicators } \\
\text { Years covered: } 1960-2015 \\
\text { Country Coverage: } 227\end{array}$ \\
\hline ruleoLaw & $\begin{array}{l}\text { Percentile ranking of the Rule of law index with higher } \\
\text { values indicating better institutional quality }\end{array}$ & $\begin{array}{l}\text { World Governance Indicators } \\
\text { Years covered: } 1996-2015 \\
\text { Country Coverage: } 215\end{array}$ \\
\hline eduSchlg & Educational Attainment for Population Aged 25 and Over & $\begin{array}{l}\text { Barro and Lee (2013) Educational } \\
\text { Attainment } \\
\text { Years covered: } 1960-2010 \\
\text { Country Coverage: } 146\end{array}$ \\
\hline $\begin{array}{l}\text { exrStabl } \\
\text { monIndep }\end{array}$ & $\begin{array}{l}\text { Exchange rate stability and Monetary independence } \\
\text { indices }\end{array}$ & $\begin{array}{l}\text { Aizenman, Chinn, and Ito. The } \\
\text { Trilemma Indexes } \\
\text { Years covered: } 1970-2014 \\
\text { Country Coverage: } 170\end{array}$ \\
\hline fxReserv & $\begin{array}{l}\text { Foreign reserves accumulation (billion US\$) } \\
\text { [correlation with GDP = .55; with reserves/GDP = .25] }\end{array}$ & $\begin{array}{l}\text { Economist Intelligence Unit } \\
\text { Years covered: 1993-2014 } \\
\text { Country Coverage: } 206\end{array}$ \\
\hline finCrisi & $\begin{array}{l}\text { A dummy variable indicating any type of Reinhart-Rogoff } \\
\text { (RR) financial crises }\end{array}$ & $\begin{array}{l}\text { Reinhart and Rogoff (2009). This time } \\
\text { is different } \\
\text { Years covered: } 1800-2010 \\
\text { Country Coverage: } 70\end{array}$ \\
\hline exrEffec & Real Effective Exchange Rates, CPI index & $\begin{array}{l}\text { IMF. International Financial Statistics } \\
\text { Years covered: 1960-2015 } \\
\text { Country Coverage: } 95\end{array}$ \\
\hline warConfl & $\begin{array}{l}\text { Measuring the intensity of battle related death in a given } \\
\text { year }\end{array}$ & $\begin{array}{l}\text { UCDP/PRIO Armed Conflict Dataset } \\
\text { Years covered: 1946-2015 } \\
\text { Country Coverage: } 153\end{array}$ \\
\hline disaster & $\begin{array}{l}\text { Total number of death per year resulting from a nature } \\
\text { disaster }\end{array}$ & $\begin{array}{l}\text { EM-DAT International Disaster } \\
\text { Database } \\
\text { Years covered: } 1900-2016 \\
\text { Country Coverage: } 217\end{array}$ \\
\hline chknBalc & $\begin{array}{l}\text { Starts off with a value of } 1 \text { and rises with competitiveness } \\
\text { of executive elections, the existence of additional } \\
\text { legislative chambers, divided government, the number of } \\
\text { coalition parties }\end{array}$ & $\begin{array}{l}\text { Database of Political Institutions } 2015 \\
\text { update. Inter-American Development } \\
\text { Bank. Updated version of Beck et al. } \\
\text { (2001) and Keefer and Stasavage (2003) } \\
\text { Years covered: } 1975-2015 \\
\text { Country Coverage: } 181\end{array}$ \\
\hline
\end{tabular}




\begin{tabular}{|c|c|c|}
\hline polPolar & $\begin{array}{l}\text { The maximum ideological difference (left-right-center } \\
\text { orientation) between the chief executive's party and the } \\
\text { four largest parties of the legislature based on seat shares }\end{array}$ & $\begin{array}{l}\text { Database of Political Institutions } 2015 \\
\text { update. Inter-American Development } \\
\text { Bank. Updated version of Beck et al. } \\
\text { (2001) and Keefer and Stasavage (2003) } \\
\text { Years covered: } 1975-2015 \\
\text { Country Coverage: } 181\end{array}$ \\
\hline polStabl & $\begin{array}{l}\text { Polity Score - captures the regime authority spectrum on a } \\
21 \text {-pont scale ranging from }-10 \text { (hereditary monarchy) to } \\
+10 \text { (consolidated democracy) }\end{array}$ & $\begin{array}{l}\text { Marshall and Jaggers (2002). } \\
\text { Years covered: 1800-2015 } \\
\text { Country Coverage: } 193\end{array}$ \\
\hline exeConst & $\begin{array}{l}\text { The variable is between } 0 \text { and } 10 \text { measuring the extent of } \\
\text { institutionalized constraints on the decision making powers } \\
\text { of chief executives. }\end{array}$ & $\begin{array}{l}\text { Marshall and Jaggers (2002). } \\
\text { Years covered: } 1800-2015 \\
\text { Country Coverage: } 193\end{array}$ \\
\hline econFree & Index of economic freedom. & $\begin{array}{l}\text { Fraser Institute } \\
\text { Years covered: } 1970-2014 \\
\text { Country Coverage: } 159\end{array}$ \\
\hline usIntRat & $\begin{array}{l}\text { US interest rates on medium and long term government } \\
\text { bonds. Percent per Annum }\end{array}$ & $\begin{array}{l}\text { IMF. International Financial Statistics } \\
\text { Years covered: 1954-2016 }\end{array}$ \\
\hline globGrwt & Annual global GDP growth. & $\begin{array}{l}\text { IMF. World Economic Outlook } \\
\text { Years covered: } 1990-2016\end{array}$ \\
\hline globFVol & $\begin{array}{l}\text { Global Volatility Index (VXO) calculated by the Chicago } \\
\text { Board Options Exchange. }\end{array}$ & $\begin{array}{l}\text { Chicago Board Options Exchange } \\
\text { Years covered: } 1990-2016\end{array}$ \\
\hline
\end{tabular}

Source: Authors. 